to describe and interpret important symptoms and signs, and briefly to discuss the more common disorders in which they occur.'

'The occasional criticism has been voiced so that a text on physical diagnosis should not contain discussions of clinical entities. I can only emphasize again my conviction, on which the twelfth edition was based, that physical signs can be intelligently taught and intelligently learned only in their relationship to and not apart from the other aspects of disease.'

The reviewer happens for many years to have been engaged in a special ${ }^{*}$ branch of medicine but has recently returned to more general medicine. During the last year he has read a large number of books on general medicine but he can truthfully say that there is no book he has read which he has found so valuable as this one. Physical diagnosis in these days of laboratory medicine tends to be neglected. periodical reading of this book can be recommended to those in general practice and in specialized practice as possibly the best method of improving one's standard of medical practice. Excellently printed on good paper, well bound and with nearly 400 illustrations, it is splendid value for money.

\section{J. L.}

\section{STEDMAN'S PRACTICAL MEDICAL DICTIONARY,}

By Stanley Thomas Garber, B.S., M.D. Fifteenth Revised Edition. 1942. Baillière, Tindall and Cox, London. Pp. Xv plus 1257. Illustrated.

Price, 42s.

THIs is a fifteenth edition of the dictionary and possibly the best of its kind. It has been thoroughly revised and completely reset in new type. Hundreds of new titles have been headed and numerous obsolete terms have been omitted.

A fine production.

J. I.

\section{BOOKS RECEIVED}

1. A Descriptive Atlas of Radiographs : An Aid to Modern Clinical Methods. By A. P. Bertwistle, M.B. ch.B., F.R.C.s. (Edin.). Fifth Edition, Revised and Enlarged. 1942. Published by Henry Kimpton, London. Pp. xxxii plus 584, with 879 illustrations. Price, $42 s$.

2. The British Encyclopædia of Medical Practice including Medicine, Surgery, Obstetrics, Gynæcology and other Special Subjects: Surveys and Abstracts, 1941-42 and Cumulative Supplement, 1941-42. Under the general Editorship of Sir Humphry Rolleston, $B t$. G.C.v.o., K.C.B., M.D., D.Sc., D.C.L., LL.D. Butterworth and Company, Limited, London. Pp. vi plus 432 plus 49 in Surveys and Abstracts and Pp. 289 in Cumulative Supplement. Price (not stated).

3. Alarming Heart Attacks-Serious and Innocent. By H. O. Gunewardene, M.B., B.s. (Lond.), D.M.R.E. (Cantab.). Published by the author. Printed at the Ceylon Daily News Press, Lake House, McCallum Road, Colombo. Pp. 61. Illustrated.' Price (not stated).

4. Gold Therapy in Tuberculosis. By Dr. C Dwarakanath, L.I.M. (Madras) and z.T. (Hamburg 'Varsity). 1943. Published by the author, 'Nut Shell ' Kilpauk, Madras, and Printed by Gordon and Company, Limited, Triplicane, Madras. Pp. ii plus 61 Illustrated. Price, Rs. 2-8.

5 Climate and.Labour: An Enquiry into the Influence of Climate on Mental and Physical Work. By W. Burridge, D.M., M.A. (Oxon.), F.N.I., F.N.A.S 1944. (Lucknow University Studies.) Messrs. Kitabistan, 17A, Kamala Nehru Road, Allahabad. Pp. 167. Price, Rs. 5-4.

6. Psychopathology : A Survey of Modern Approaches. By J. Ernest Nicole, L.M.S.S.A., D.P., M.R.C.P.\& S Third Edition. 1942. Baillière, Tindall and Cox, London. Pp. xi plus 265. Price, 15 s.

7. Hermaphrodites. The Human Intersex. By A. P. Cawadias, o.B.E., M.D., F.R.c.P. 1943. William Heineman Medical Books Limited, Iondon. Pp. ix plus 78. Illustrated. Price, 15 s.

\section{Correspondence}

\section{NOVARSENOBILLON AND MAPHARSIDE IN THE TREATMENT OF THE ATTACK OF MALARIA}

SIR,-I was greatly interested in your paper on the treatment of the attack of malaria by novarsenobillon and mapharside published in the March 1944 issue of your Gazette. In the last paragraph of your paper you mention the possibility that combined treatment of one of the organic arsenicals with quinine might possibly reduce the relapse rate considerably. This question I have tried to answer in a number of cases too small yet for publication but with such encouraging results that this short note appears already justified.

From time to time I am consulted by patients giving a long history of frequent relapses of malaria in spite of sufficient treatment with quinine as well as atebrin. Blood examination during. the relapse reveals the presence of Plasmodium vivax. For the same reasons as stated by you that one can never be quite sure that there may not be also an infection with $P$. falciparum I have not felt justified in starting treatment at once with neoarsphenamine or mapharside but have always begun treatment with two or three days quinine followed by four or five intravenous injections of neoarsphenamine or mapharside. In all of these cases with the exception of one the result has been cessation of attacks. This treatment was also given to one patient who suffered from a chronic infection of $P$. falciparum with numerous attacks of low fever and also some attacks of very high temperature. After a holiday in the hills of four weeks he was suffering from an attack in Calcutta while on his way to Assam. The combined quinine mapharside treatment kept him free from attacks for over six months when he fell ill again, but this time with tertian malaria, obviously a new infection.

The number of my cases of this relapsing type treated in the way described above is statistically insignificant. They comprise only about ten cases, and one relapsed after the treatment. All the others lost their malaria infection by this method after a history of many months of unsuccessful treatment with sufficient amounts of quinine and atebrin.

\section{3, Chowringhee Road,}

RUDOLF TREU, M.D., L.R.C.P., etc.

CALCUTTA,

11th April, 1944

[Note.-It is believed that studies are now being made in India on the value of the neoarsphenamines in combination with quinine and atebrin in the prevention of malaria relapses, and that the results have not been very encouraging.

General experience indicates that the value of arsenic in $P$. falciparum infections is very little.-EDIron, I. $M . G$.

\section{NAGA SORE}

SIR,-Recently I read with interest the 'Report on the Occurrence of Naga Sore in Calcutta' by Drs. Panja and Ghosh in your January issue.

In my sixteen years' practice, the disease was rarely found here; though it has been always endemic in the hilly parts 30 to 40 miles off from this tea estate. In 1942 , some labourers who were sent for road work to the hills near the Burma border returned with typical Naga sores in their lower extremities, and since then the disease has been endemic here. The doctors of the neighbouring tea estates have also similar experience. So, I quite concur with the view of the authors that the original source of the infection was from imported cases amongst the evacuees from Burma passing through Assam. 